
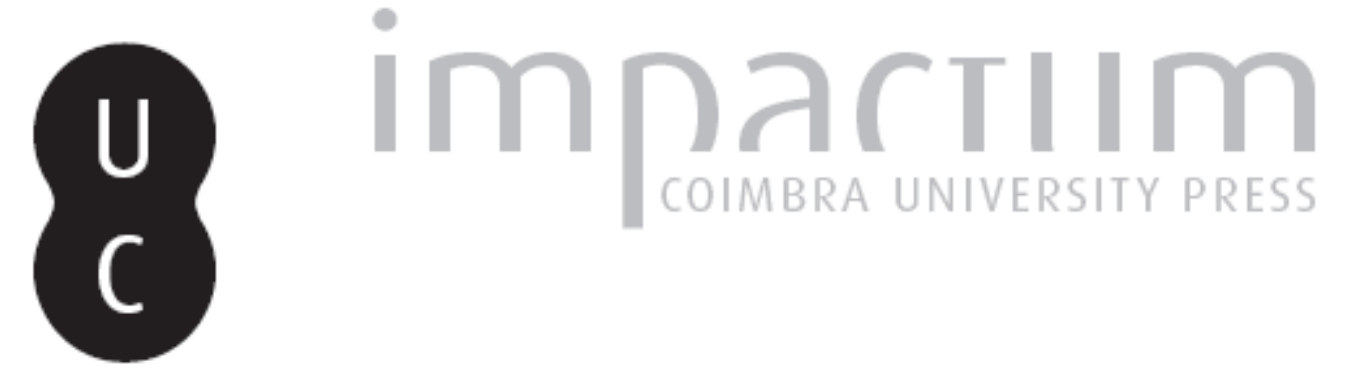

\title{
Generative copies: modernist architecture and urbanism in Brazil
}

Publicado por: Editorial do Departamento de Arquitetura

URL

persistente:

URI:http://hdl.handle.net/10316.2/37391

DOI:

DOI:http://dx.doi.org/10.14195/1647-8681_2_1

Accessed : $\quad$ 26-Apr-2023 02:59:06

A navegação consulta e descarregamento dos títulos inseridos nas Bibliotecas Digitais UC Digitalis, UC Pombalina e UC Impactum, pressupõem a aceitação plena e sem reservas dos Termos e Condições de Uso destas Bibliotecas Digitais, disponíveis em https://digitalis.uc.pt/pt-pt/termos.

Conforme exposto nos referidos Termos e Condições de Uso, o descarregamento de títulos de acesso restrito requer uma licença válida de autorização devendo o utilizador aceder ao(s) documento(s) a partir de um endereço de IP da instituição detentora da supramencionada licença.

Ao utilizador é apenas permitido o descarregamento para uso pessoal, pelo que o emprego do(s) título(s) descarregado(s) para outro fim, designadamente comercial, carece de autorização do respetivo autor ou editor da obra.

Na medida em que todas as obras da UC Digitalis se encontram protegidas pelo Código do Direito de Autor e Direitos Conexos e demais legislação aplicável, toda a cópia, parcial ou total, deste documento, nos casos em que é legalmente admitida, deverá conter ou fazer-se acompanhar por este aviso. 

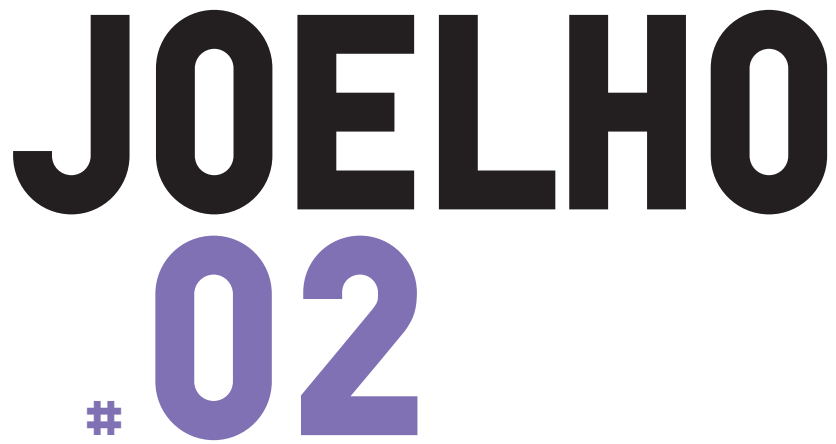

INTERSECCÓES:

ANTROPOLOGIA

E ARQUITECTURA

Coordenação:

Paulo Providência

Sandra Xavier

Luís Quintais

Comunicações:

Georges Teyssot

James Holston

João Leal

Sergio Fernandez

Comentários:

Jorge Figueira

José António Bandeirinha

Luís Quintais

Paulo Providência

Sandra Xavier 


\section{James Holston}

\section{Generative Copies:}

Modernist Architecture

and Urbanism in Brazil

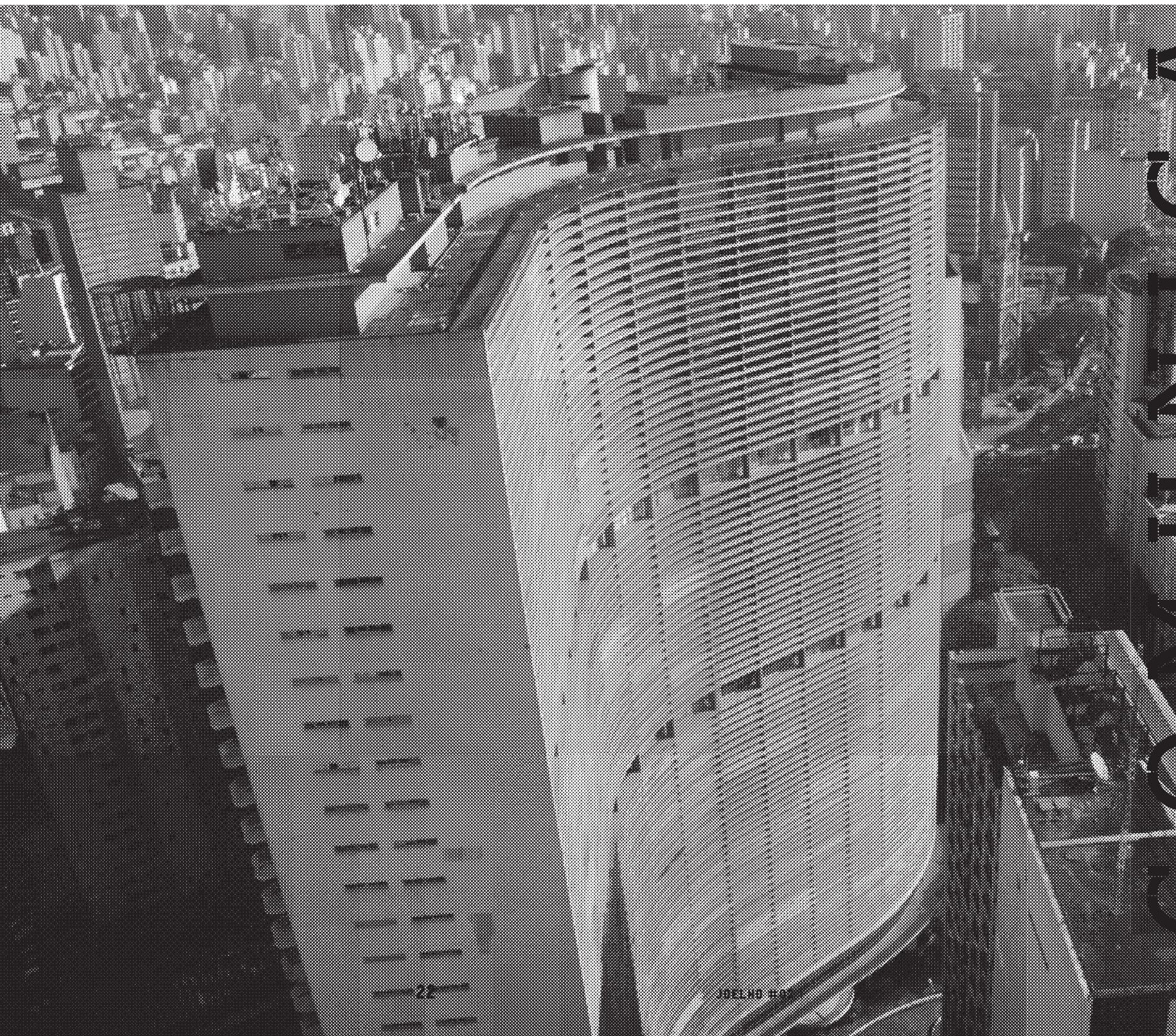


I am an anthropologist investigating architecture. I also trained professionally as an architect. Let me begin by suggesting how these studies intersect in this essay. Both anthropology and architecture may be practiced as investigations of the present, but of different sorts. Anthropology's practice is a combination of ethnographic, comparative, and historical methods designed to detect both the structures and the contingencies that render the present inhabitable. In addition to detection, however, it's aim is to problematize this inhabitation. It does so by focusing on its assumptions and contradictions, as evident in what people say and do and primarily in the gaps between the two. The kind of anthropology I am talking about construes these foci as starting points - problems, puzzles, "crimes" - for an investigation of three trajectories. One traces these foci through their genealogies of historical transformation to show how they structure the present as an insurgence of the past. The other emphasizes that this historical structuring is typically lived as a taken-for-granted because it generally arrives in the present, so to speak, unannounced and unproblematized.

The third investigates the consequences of this unproblematization. It shows that the organizations of life in the present are culturally robust as historical taken-for-granteds. But in studying the conflicts of daily life, this aspect of anthropology's investigation also shows that the taken-for-granteds of the present are fragile because their organizations are produced at the intersection of many historical formulations that are themselves often in conflict. These intersections create the contingencies of the present that become the idioms of conflicts and that anthropological research makes visible. The sum of these three anthropological investigations defamiliarizes the way people live. This defamiliarization is anthropology's critical objective. It renders the present strange and indicates its emergent conditions of change.

Architecture is also an investigation of the inhabitation of the present. But unlike anthropology, it generally strives to become normative, predictive, and prescriptive of the present, shaping it, stone by stone, plan by plan, becoming the structure of the present. It is, moreover, a structuring based on a prior script that becomes imposed on the present as two dimensional plans take on three dimensional form. In this process, architecture is necessarily utopian. Whoever designed a family house for divorce, for even the possibility of divorce? As normative structure and script, however, a decisive problem in architecture is to deal with the inevitable contingencies of living, with the multiple forces and factors that are always unmaking and remaking our lives in the present we inhabit. The "heavy" structures of architecture - especially the fetishized objects of modernist architecture, as I argue in this essay - accompany such changes with difficulty. Instead, the contingencies of living often render architecture isolated, anachronistic, even oppressive.

I believe that anthropology, as an investigation of the present, has important things to say to architecture about this problem. In what

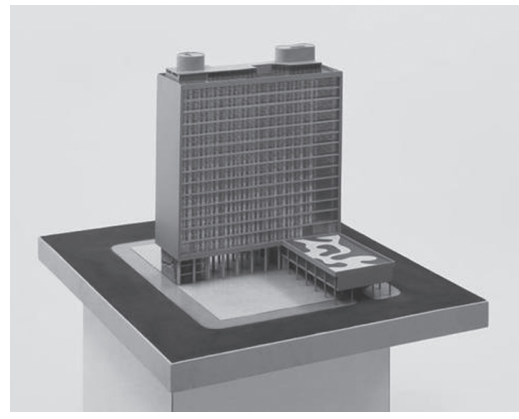

1. Model of the Ministry of Education and Culture in Rio de Janeiro, 1937. (@ UCB AVRL)

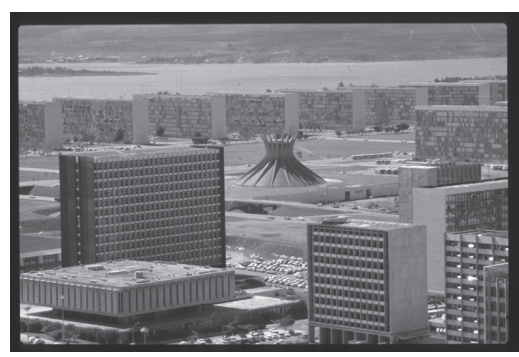

2. Brasília, view (back to front): Lake, Esplanade of the Ministries, Cultural Sectors (with Cathedral), Public Service and State Enterprise Sectors, Residential Sectors, and Banking Sectors, 1981. 


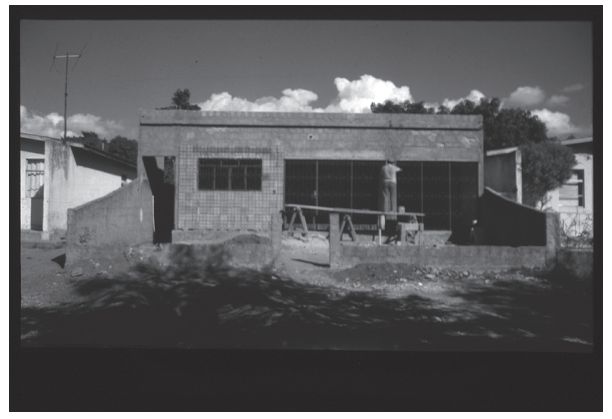

3. Autoconstructed house in the satellite city of Sobradinho, periphery of Brasília, 1980s.

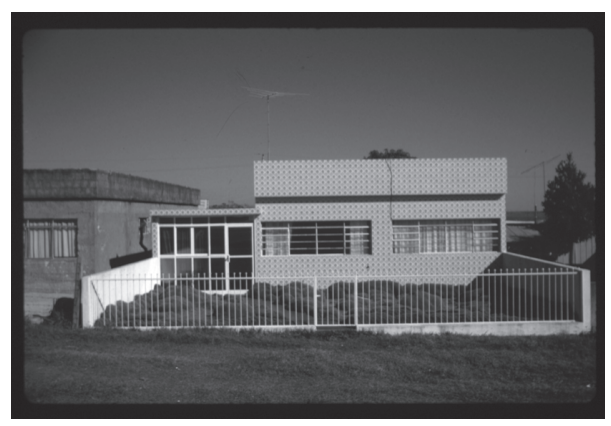

4. Autoconstructed house in the satellite city of Sobradinho, periphery of Brasilia, 1980s.

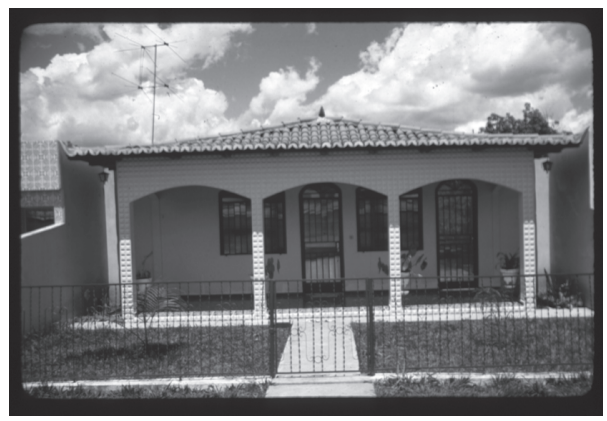

5. Autoconstructed house in the satellite city of Sobradinho, periphery of Brasilia, 1980s. follows, I take CIAM modernism as a case in point to explore this proposition.1

CIAM modernism is one of the most enduring, reproduced, and recognized standards of architecture and planning the world has known. For all the criticism it has endured, from every angle and imagination (mine included, see Holston 1989), it remains arguably the most coherent paradigm of the architected environment globally. To be sure, there are successful competitors. But most derive directly from it in both form and strategy. Moreover, its practitioners and sponsors - architects, planners, developers, governments, international agencies, local organizations, corporations, and so forth - range across the entire political spectrum. The global preeminence of CIAM's modernist lexicon may be attributed to a number of factors: its formal brilliance in subverting the architectural conventions of its opponents, its dominance in architectural education and professional organization, and, perhaps above all, its elective affinity with modernity itself, that is, its ability to communicate both the aspirations and the tragedies of being modern - the bravado of being able to rewrite history and leap into a radiant future by means of "total design" as well as the aloneness of mass life registered in building forms whose outlines appear selfcontained and detached.

The very success of CIAM suggests a means to address an important question: Does CIAM's globalized standards homogenize the built environment, producing look-alike urban landscapes that flatten urban life itself into sameness? A sameness without vitality, one that cannot consider contingency? One might ask the same question of other successful architectures, especially those that accompany empire. One might ask it, for example, of the ubiquity of the Doric column and entablature, though the destiny of classical architecture as pure appliqué gave it an adaptable superficiality inherently unavailable to CIAM's sculptural modeling. But without doubt, one of the frequent charges leveled against CIAM modernism is homogenization. By that, I mean the reduction of social, cultural, material, and functional differences to templates of architectural solution produced through the universalization of a particular conceptualization of architecture and its conventions of form, space, and design. My focus in these comments is in part on these conventions. However, my larger concern is with a problem of copying, the problem of reiterating and transplanting recognizable conventions that is, necessarily, a component of the propagation of any model, style, and paradigm, including architecture.

\section{High and Low Copies}

I take as my case one example of such propagation, namely, Brazil's national investment in CIAM modernist architecture. This modernism is on display in all Brazilian cities. Among its various renditions, one is internationally renowned for transforming the lexicon of CIAM into brilliant Brazilian performances. I refer to the gems of this avant- 
garde that Brazil's world-famous architects continue to produce - the buildings of the Ministry of Education and Culture, Copan, and Brasília to note a few (Figs.1 and 2). Although their types and functions vary, they are designed by architects - such as Paulo Mendes da Rocha and Oscar Niemeyer - who maintain a highly competitive dialogue through them not only with each other but also with the ambitions of design professionals globally.

Another performance of this modernism is not well-known outside of Brazil. Yet examples are found by the thousands in modest residential neighborhoods throughout the country: single-family homes that are owner designed and built, an "autoconstruction" (autoconstrução) as Brazilians call it, produced by both the working and the middle classes without professional architects (Fig. 3). Sometimes labeled "popular modernism," its designer/builders are no less concerned with using modernist architecture to narrate, to say something about being modern Brazilians (Fig. 4). However, their modernist means are routinely dismissed by both native and foreign architects, critics, and historians as kitsch, degenerative, vulgar, and worthless imitations precisely because they are vernacular.

One way to bring these two performances into critical relation is to show that while they sometimes homogenize, at other times these architectural modernisms create active, participatory, and diverse publics. The question is, what conditions produce each outcome? Surely one condition to evaluate concerns the means and modes of their dissemination. Neither "high" nor "low" versions are imposed undesired in Brazil. Rather, both are widely demanded and consumed. Studies of Brazilian architecture demonstrate the popularity of modernist architecture among all classes of Brazilians (Figs.5 and 6). However, most focus exclusively on the production of star architects for wealthy clients. A few consider autoconstruction among the lower and middle classes (e.g., Holston 1991 and Lara 2008).2

These studies highlight two crucial sources of dissemination: modernism's propagation by the state - that is, its sponsorship in projects built by various local and national administrations of government - and its appearance in the media, in "coffee-table" magazines, television (especially in telenovelas and advertisements), and in trade magazines. These sources expose massive numbers of Brazilians to modernist architecture, turning this architecture into a widely legible, compelling, and innovative paradigm of communication about the modern and its prospects for producing new personal, social, and national identities.

Especially between the 1930s and 1970s, but continuing today, Brazilians of all classes embraced the "new architecture" because they saw in it a means to express their aspirations to invent new futures that were simultaneously national and personal, the destiny of one identified with that of the other. To both the state and its citizens, the modernist vocabulary articulated a way of leaping over a backward, rustic,

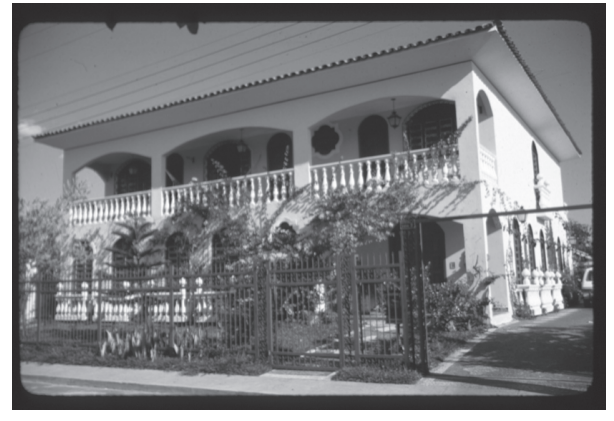

6. House in the Lago Sul neighborhood of Brasília, 1980 s.

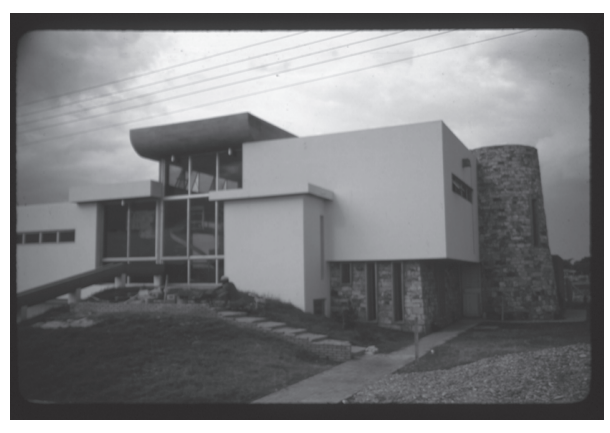

7. House in the Lago Sul neighborhood of Brasilia, 1980 s.

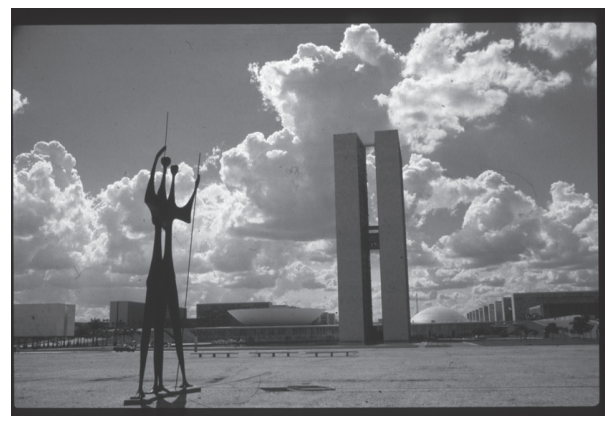

8. Plaza of the Three Powers with a view of the National Congress and the Statue The Warriors, Brasília, 1980. 


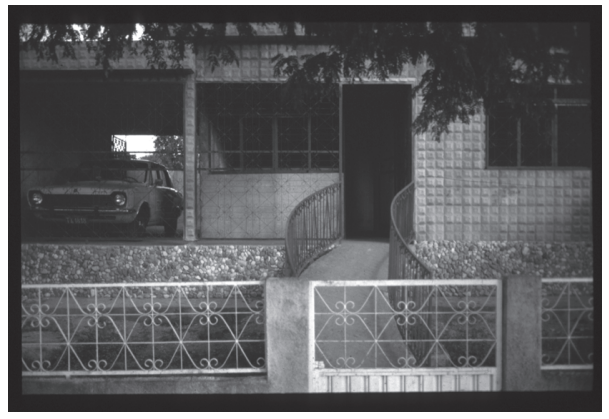

9. Autoconstructed house in the satellite city of Sobradinho, periphery of Brasília, 1980s.

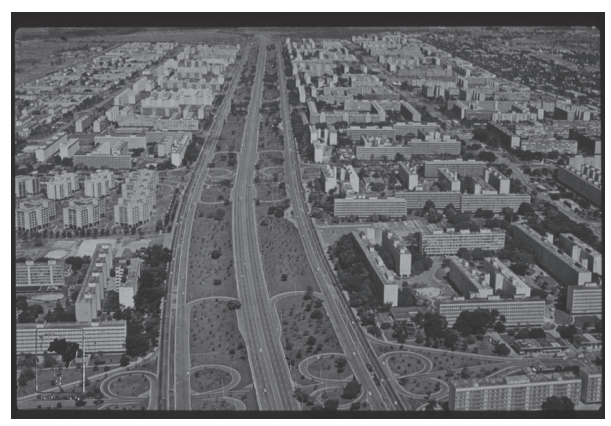

10. Aerial view of the South Wing, Plano Piloto, Brasília, 1981.

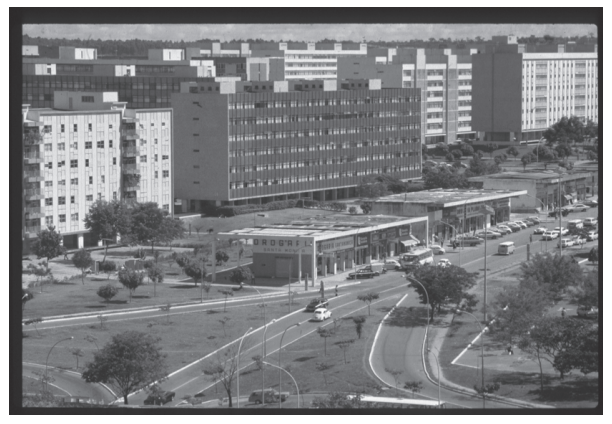

11. Local Commerical Sector 102 South, Plano Piloto, Brasília, 1980. and colonial past into a radiant industrial urban future constructed symbolically and concretely with the columns, canopies, and brisessoleils of modernist architecture. It expressed a direct equation: building modern indicates being modern and being modern means innovation. Thus President Jucelino Kubitschek (1975: 62) justified his support for Lúcio Costa's modernist Master Plan for Brasília in the following terms: "Owing to the need to constitute a base of radiation of a pioneering system [of development in all areas] that would bring to civilization an unrevealed universe, [Brasília] had to be, perforce, a metropolis with different characteristics that would ignore the contemporary reality and would be turned, with all of its constitutive elements, toward the future." This "spirit of Brasília" as it was often called - this invocation to break with the past, to dare to imagine a different future, to embrace the modern as a field for experiment and risk - was most legibly captured in Brazil's architectural production. However, it was also articulated in other important aspects of Brazil's emerging urbanity, from television and cinema to participatory citizenship.

Nevertheless, Brazil's cosmopolitan and popular performances of architectural modernisms remain embroiled in intense debates about the worth of each. These debates have the same root issue: the judgment that the copy is inferior and that copying is inauthentic, if not degenerative. There is a double iteration of this problem in Brazilian architectural modernism (Fig. 7). On the one hand, the importation of European avant-garde modernism to the "periphery" of Brazil is deemed artificial and false because exogenous; on the other, the Brazilian masters of the high modern "made in Brazil" dismiss its translation into an "unarchitected" vernacular as mimetic kitsch.

The problem of the foreign copy that produces alienation at the core of Brazilian identity is, however, hardly new. At least since the founding of the Republic at the end of nineteenth century, the thesis that Brazilian society results from the dichotomous development of "two Brazils" - each foreign to the other - is commonly expressed in literature, art, social science, and religion, as well as everyday interaction. The one Brazil is coastal, urban, capitalist, cosmopolitan, rational, national, and modern. The other is backland, feudal, mystical, dark, and primitive. Most Brazilian authors are located in the former, even those who write about the other Brazil. What is curious is not that some despise the backland Brazil as degenerate, even though they may describe it as little-known and remote. It is more that this Brazil emerges in their reflections as the genuine one, the real and popular Brazil, in contrast to the urbane Brazil which is artificial as a European or American transplant. The former, unfamiliar and primitive, is nevertheless authentic. The latter, modern and urban, is, to use a phrase Roberto Schwarz (1977) made famous, a copy "out of place" of European and American ideals of progress, civility, law, and aesthetics. 
Brazilian architectural modernism doubly suffers this castigation of being out of place. Much of the high modern rejoinder to this charge argues that it is, after all, an authentic Brazilian production because it uniquely combines European modernism with elements of Brazilian baroque. In digesting both, it produces an "anthropofagic" original.3 It seems to me, however, that the important point is not to debate whether this or that element implies a continuation or reinterpretation of a specific style from the past but to analyze the selective uses of the past for present purposes (Fig. 8). What the argument about authenticity misses is that with or without supposedly baroque curves and decorative ceramic tile, the Brazilian renditions of CIAM's global modernism constitute a copying that is itself generative and original. In a fundamental sense, the very purpose of its exemplars (think of Brasília) is to capture the spirit of the modern by means of its likeness. Its supposedly baroque elements are irrelevant to this project. Rather, it is the homeopathic relation to the model - brilliantly executed to be sure in many Brazilian cases - that gives the copy its transformative power. In other words, its power resides precisely in the display of likeness, in a replication of the model in new places. Paradoxically, it is this replication of the same model in different locations that gives it the possibility of signifying a diversity of local narratives about being modern.4

By the same token (Fig. 9), the reproductions of autoconstructed popular modernism in Brazil are also original copies, creative and productive in their own right. It is far less important that popular modernist houses, like their cosmopolitan counterparts, combine modernist and nonmodernist elements in sometimes contradictory ways - a flat stuccoed entablature behind which is hidden a pitched title roof or a modernist façade built on a rusticated stone base and enclosing a colonial plan (Compare Figs. 7 and 9). What is significant is that the appropriations and recombinations of this popular modernism succeeded in creating a massively legible narrative about being modern in Brazil, and therefore a diverse public to digest it through the invention of contemporary life written, commented on, and read in architecture. To dismiss these houses as low quality, reject them as sources of aesthetic innovation, and ridicule them as kitsch, as Brazil's own high modernist architects have done, is to miss something fundamental about architecture itself as a record of human aspiration and achievement.

Replication establishes the possibility of diverse publics speaking the same language. But its realization - that is, the transformation of the copy into a generative transplant with a life of its own - depends on local conditions of production. In what follows, I contrast two decisive conditions of producing CIAM modernist architecture in Brazil, that of master planning and total design and that which I describe as urban layering, montage, and contingency.

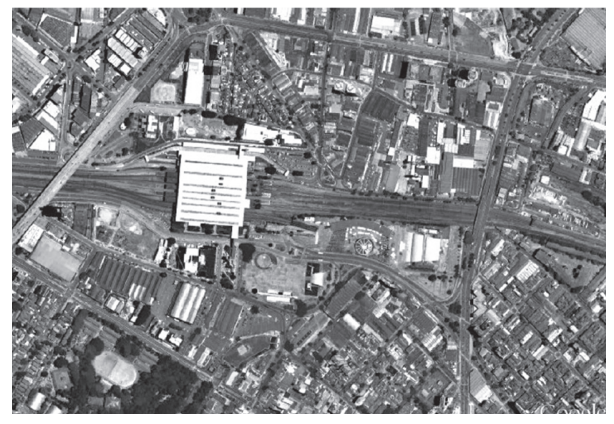

12. Aerial view of the Memorial of Latin America, São Paulo, 2009. (Google Maps, 2009)

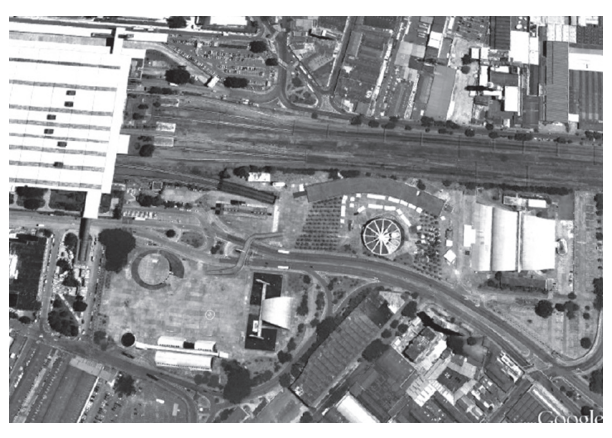

13. Aerial view of the Memorial of Latin America, São Paulo, 2009. (Google Maps, 2009)

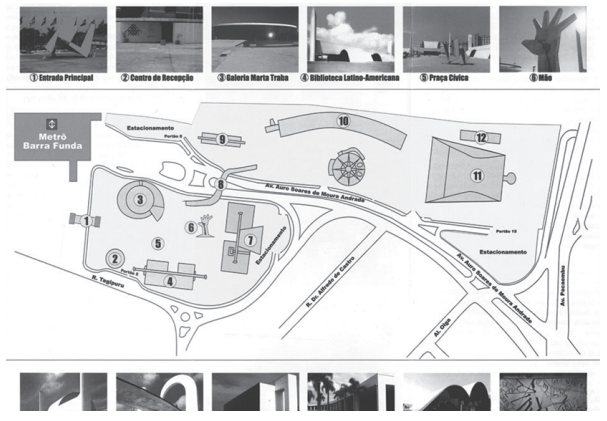

14. Memorial of Latin America, São Paulo, site plan, 2009. (http://www.memorial.sp.gov.br/ memorial/index.jsp) 


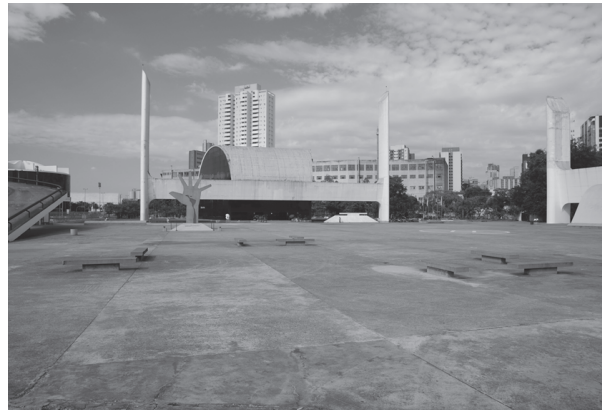

15. Memorial of Latin America, São Paulo, Civic Square, 2010.

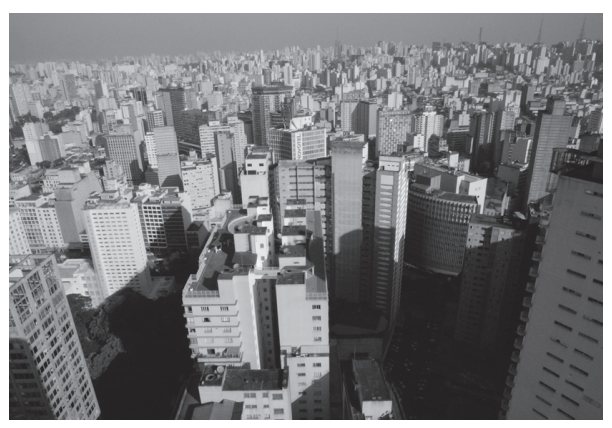

16. View of central São Paulo from the top of Edifício Italia, 2009.

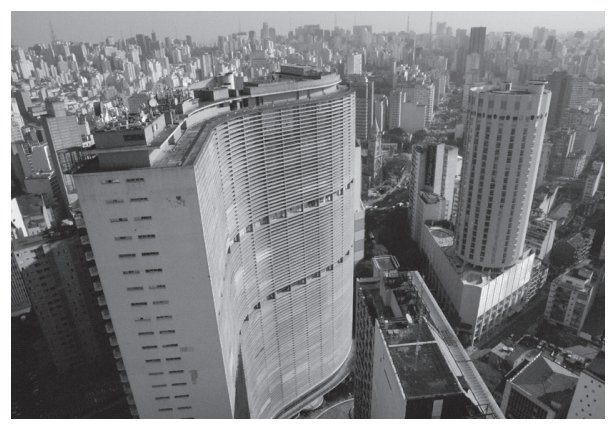

17. View of Copan and its urban context from the Edifício Italia, 2009.

\section{Modernist Master Planning and Total Design}

My argument is that when modernist architecture is produced as a totally designed urban environment using modernist conventions of design and planning, the result tends to flatten both building and space into repetitious sameness, draining their vitality and interest. In contrast, when modernist architecture is produced in conditions of urban density sufficient to generate a layering of different kinds, lexicons, and uses of forms and spaces, the result animates both building and space, independent of the aesthetic coordination of the whole or the aesthetic merit of individual elements. I push the last part of my argument to extreme, perhaps. But I do so to emphasize that while valuable, aesthetic coordination and merit are far less important than other factors in animating urban architecture and its cityscape. To illustrate, I contrast several examples by the same architect, Oscar Niemeyer. First, I discuss the spatial logic of modernist totalization in planning and design, using the examples of a whole cityscape (Brasília, Figs. 2, 8, 10-11) and a single building that assumes such a whole (the Memorial of Latin America in São Paulo, Figs. 12-15). I then discuss the dense urban layering of a single building, Copan, in downtown São Paulo (Figs. 16-27).

As I have elsewhere developed an extensive critical analysis of modernist total design and master planning (see Holston 1989), assessing both its formal and social assumptions, methods, and consequences, I only summarize some essential points here. CIAM's principal paradigm of urban planning is to impose upon the existing city (or to lay out from scratch) a totality of new conditions that organizes the entire cityscape in terms of the coherence of its spatial and functional logic (Fig. 10). Thus its strategy for city making is totalization. I have in mind not only entire cityscapes like Brasília, Dubai, central Houston (or Dallas, Detroit, Saint Louis, and so forth), Eastern European "new cities," and U.S. suburban developments. I also refer to fragments of the total vision that assume the modernist whole in relation to their site and surroundings regardless of function, from a business sector like Berrini to a single building like the Memorial of Latin America, both in São Paulo.

In its standard expression, the functional logic of modernist total planning insists on a separation of the urban "functions" into zones of residence, commerce, work, traffic, recreation, and administration, with entire sectors of the city devoted uniformly to one zone. Nevertheless, in state-sponsored examples such as Brasília, an additional kind of homogenization often occurs. On the one hand, the modern master plan displaces institutions traditionally centered in a private sphere of social life to a new state-sponsored public sphere of residence and work. On the other, its architecture renders illegible the what used to be (in non or pre-modernist contexts) taken-for-granted representational distinctions between these institutions. Its strategy of total design is thus a double defamiliarization. 
As a result, for example, the functions of work and residence in Brasília lose their traditional separation when the latter is assigned on the basis of work affiliation, as it was generally until 1965 and still is in some sectors. Hence, Bank of Brazil employees reside in one superquadra, those of the Air Force Ministry in another, those of Congress in yet another, and so forth. In addition, these functions become architecturally indistinguishable as the buildings of work and residence receive similar massing and fenestration and thereby lose their traditional symbolic differentiation.5 The first generation of residents considered that this homogenization produced an estrangement akin to an illness that they called brasilite or "Brasíliaitis." As one resident told me, "Everything in Brasília was different. It was a shock, an illusion, because you didn't understand where people livid, or shopped, or worked, or socialized." Another said, "even the tombstones are standardized."

Another common instance of homogenizing disorientation is the sense of exposure residents experience inside the transparent glass facades of their modernist apartment buildings. With considerable irony, early residents nicknamed their transparent glass boxes "the candango's television set" - meaning that a poor man (the candango, Brasília's pioneering construction worker) could find nightly entertainment by standing in front of an apartment block to watch the interior drama of middle-class life revealed on the big screen of the illuminated facade. In response to this perceived assault on their privacy, which some link to the moralizing gaze of a new statesponsored public sphere, residents resist by putting up every kind of visual barrier - curtains, blinds, potted plants, even birdcages. The newer residential superblocks in Brasília address this problem of exposure and estrangement by significantly increasing the amount of solid exterior wall in relation to window - thereby creating nontransparent façades - and by emphasizing balconies for each apartment to distinguish buildings of residence from those of work.

It is, overwhelmingly, in the application of its spatial logic that modernism achieves an unrelenting totalization of urban life, one that once installed can only be changed by breaching the model itself. The development of this logic derives from CIAM modernism's elimination of the corridor street (the street edged with continuous building facades) as its prerequisite for modern urban organization - a plan of attack Le Corbusier announced as "the death of the street" in 1929.6 In its critique of the cities and society of European capitalism, CIAM vilified the street as a place of disease and criminality and as a structure of private property that impedes modern development. Above all, modernist architecture attacked the street because it constitutes an architectural organization of the public and private domains of social life that it sought to overturn.

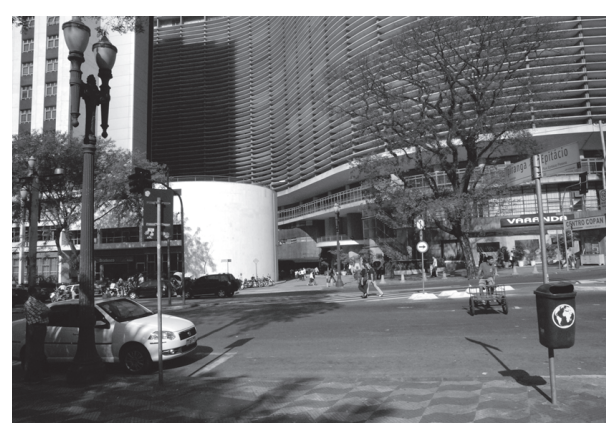

18. Copan, view of entrance hub on Avenida Ipiranga, 2009.

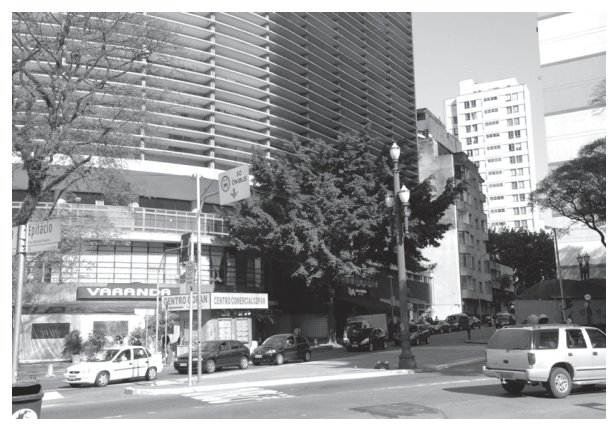

19. Copan, view of lower level along Rua Araujo, 2009. 


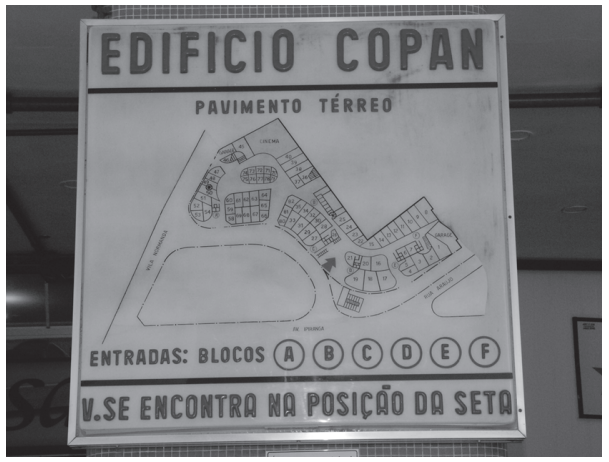

20. Copan, site plan posted inside lower level, 2009.

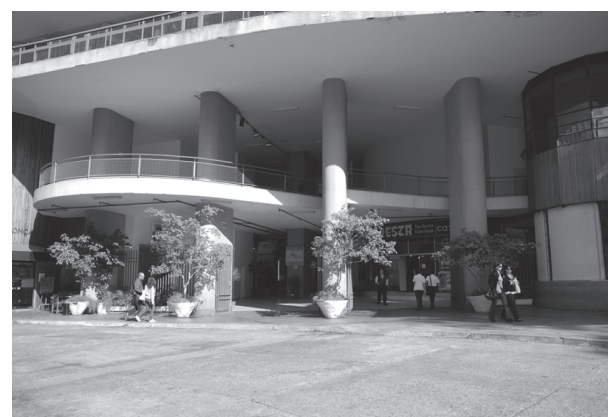

21. Copan, view of entrance and passage into building, 2010.
This organization is constituted in terms of a contrast between the street system of public spaces and the residential system of private buildings. In the kind of preindustrial urbanism modernism attacks, streets and squares are framed by facades built edge-to-edge and perceived as having the shape these frames make. Thus, streets and squares are spaces that have form, usually perceived as figures of rectangular volume (figural voids). This figural perception creates the impression that the continuous building facades are the interior walls of outdoor rooms, the public rooms of the city. The street-walls are, accordingly, ornamented, and the street-rooms furnished with benches, sculpture, fountains, and other amenities to nurture the social interactions that take place in them. The corridor street-system of spaces is thus the architectural context of the outdoor public life of preindustrial cities.

The formal spatial principle of this urbanism is not only that streets and squares are figural voids in contrast to the ground of the solids around them. It is also, as fundamentally, that these voids and solids are reversibly both figure and ground. Although space is consistently figural and building ground, these relations are easily reversed to signify public monuments and civic institutions. Think of churches and city halls gesturing to their publics as buildings broken away from the anonymous ribbon of street facades, given sculptural massing, and set into urban squares that become ground to their figural volumes. This reversal of figure and ground is the key rhetorical principle of the architectural organization of the preindustrial city, articulating its social values through processions of ambi-valent solids and voids.

By eliminating the corridor street, modernism ruptures this system of architectural signification (Figs. 10-11). Whereas preindustrial baroque cities (such as Ouro Preto in Brazil) provide an order of public and private by juxtaposing architectural conventions of repetition (ground) and exception (figure), the modernist city (such as Brasília) is conceived as the antithesis both of this mode of representation and of its represented sociopolitical order. In the modernist city, vast areas of continuous space without exception form the perceptual ground against which the solids of buildings emerge as sculptural figures. There is no relief from this absolute division of architectural labor: space is always treated as continuous and never as figural; buildings always as sculptural and never as background.

The consequences of this total inversion are profound. By asserting the primacy of open space, volumetric clarity, pure form, and geometric abstraction, modernism not only initiates a new vocabulary of form. More radically, it inverts the entire mode of perceiving architecture, turning it inside out - as if the figural solids of the modernist city have been produced in the mold of the figural voids of preindustrial urbanism. Furthermore, the modernist city negates the reversals of the traditional code by insisting on the immutability of the terms: by establishing the absolute supremacy of continuous nonfigural void, it 
transforms the ambi-valence of preindustrial planning into a monolithic spatial order. Reversals are now impossible. Modernism has imposed a total and totalizing new urban order.

While this order is obvious at the scale of an entire city built de novo, like Brasília, the destructive nature of its antagonism to the old urbanism is most palpable when the two collide in single building projects. This is because one of the distinctive features of modernist planning is that it refuses any dialogue (other than rejection) with existing urban conditions. Its unrelenting decontextualization is evident, for example, in the march of Le Corbusier's Cartesian Towers across the old Paris in his Plan Voisin (1925) or in Hilberseimer's proposed leveling of central Berlin (1927) to clear the ground for an overlay of gigantic superblocks.

Niemeyer's Memorial of Latin America inaugurated in central São Paulo in 1989 is a contemporary example, though not quite as dramatic, of the insertion of a modernist project into the fabric of an existing city (Fig. 12). It is an ensemble of freestanding objects - including nine pavilions - set on two enormous expanses of grey concrete (more than 84,000 square meters in total). A wide pre-existing street separates the two parts, which are connected by a pedestrian bridge overhead. The site is a difficult one, bounded on one side by a major thoroughfare and on another by train tracks. Yet, rather than engage the dense residential and commercial streets of the neighborhood of Barra Funda that converge on the other sides, its site planning is resolutely detached and self-referential. It makes no accommodation to these streets, no recognition of the neighborhood, no effort to bring the city to it. Its planning logic of figural objects set in open space is not, however, that of "pavilions-in-the-park" or sculpture garden, as its intention is not to be a city park or garden at all. Although there are a few trees and patches of grass - mostly around the edges, which do not invite people to relax - the vast amount of open space is paved (Fig. 13).

Rather, its project is to be a "memorial" - a remembrance and celebration - of Latin American peoples, cultures, arts, and politics (Fig. 14). It is intended as a place where the local (Brazilian) encounters the continental (Latin American) in a Civic Square, as the open space of the entrance slab is called. Distributed around this space and its other part are various buildings, including the Latin American Library, the Tiradentes Events Room (with panels depicting Latin American's colonial history), the Simón Bolivar Auditorium, the Pavilion of Creativity (permanent collection of popular arts), and the Annex of Congressionalists (for diplomatic and academic activities). As a place to discover, disseminate, and integrate "the vision" of a greater Latin America, "its vocation is," according to official information found in its pamphlets and on its web site, "the encounter of crowds, with a capacity for at least 30,000 people." As a modernist set piece, it thus reproduces the social and spatial assumptions of the entire model of CIAM urbanism, rejecting the local urban present in favor of the

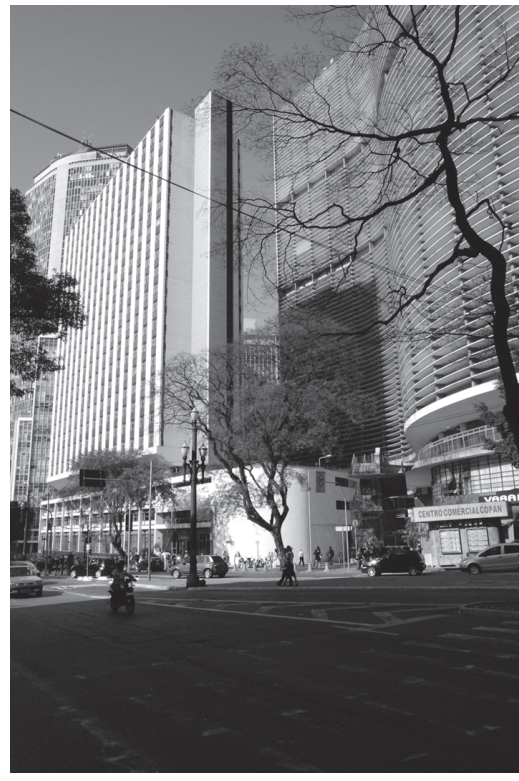

22. Copan, view along Avenida Ipiranga, 2009. 


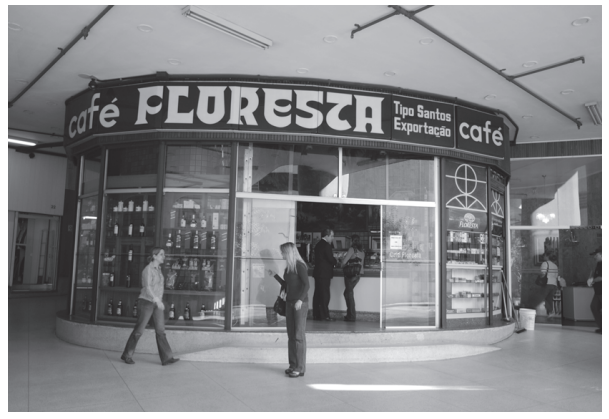

23. Copan, entrance level, 2010.

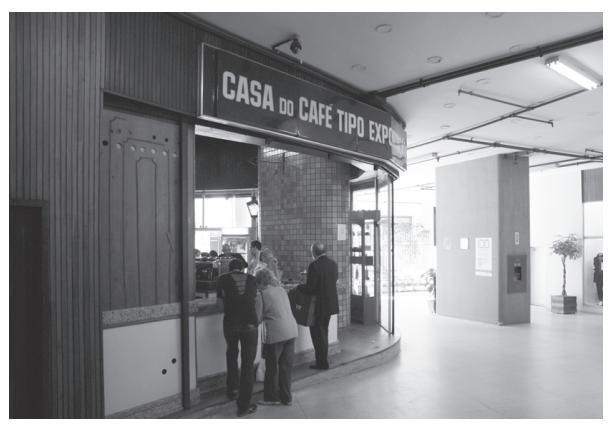

24. Copan, entrance level, 2010.

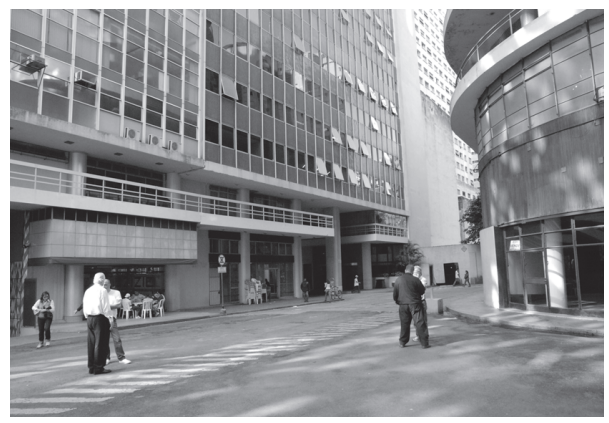

25. Copan, "civic square" at intersection of Ruas Unai and Normanda, 2009. inspiration of a primordial past and the promise of a different future.

The problem is that there is no encounter of crowds (Fig. 15). Except for major staged events and occasional tourists, the Civic Square of the Memorial is overwhelmingly empty. It is an enormous expanse of concrete devoid of life, a stained and dirty island of modernism bereft of the crowds and encounters of urban life in a city teeming with them. Just as in the open spaces of Brasília - its Plaza of the Three Powers, Esplanade of the Ministries, or the green areas of the Superquadras the modernist spatial paradigm produces no active informal daily urban public. To the contrary, its reiterations in Brazilian cities doubly deaden their vibrant outdoor public life.

On the one hand, when rendered as sculpture, always figural, architecture loses its ability to provoke a diversity of appreciations and surprises. It becomes, in effect, an ensemble of repetitious "one-liners," fixed in people's minds - when they think about it at all. Individual buildings remain self-contained outlines signifying a single form (a rectangle, cylinder, curve) or image (spaceship, crown, sails, waves, bird) that once established hardly changes. At the same time, this totalizing modernist design transforms space into mere background to figural objects. It eliminates the possibility of ambi-valent encounters between the two, establishing a uniform condition in which space loses the plasticity to become architectural form (i.e., figural void) and the vitality to be a container of social life, an outdoor room that nurtures social interaction. To the contrary, modernist monolithic space alienates social life, driving it into privatized and secured interiors. Under these conditions of production, whether applied to an entire city or a single set piece, the propagation of the modernist paradigm soon loses its affinity with innovation and experiment. Instead of original and generative, its copies become dead letter.

\section{Layered Modernism}

I turn now to a counter-example by the same architect in the same city to show that under different urban conditions, modernist architecture can animate building, space, and public. Two conditions are crucial to this animation: compelling modernist constructions to maintain and accommodate a street-system of public spaces in plan and elevation (in the case at hand, pre-existing), and producing them in contexts of sufficient density to generate a multivalent layering of forms and spaces. In most cases, the first condition tends to foster the second.

Not far from the Memorial are the old central neighborhoods of São Paulo that were built up in the 1940s, "50s, and '60s with modern residential and office towers: República, Consolação, Vila Buarque, Anhangabau, Sé, among others (Fig. 16). One block from the Republic Square and two from the famous intersection of the avenues São João and Ipiranga, set on a deep lot in the middle of its block that fronts onto Ipiranga, surrounded on all sides by buildings of different shapes, sizes, and surfaces that grew up over the same decades, is Copan, 
an enormous curvilinear housing block designed by Niemeyer and completed in 1953 (Fig. 17). It has 38 floors above ground and 2 below and a total constructed area of 116,000m2. Its 32 residential floors are raised by pilotis and walls above a four-storey commercial space. They contain 1160 apartments of various sizes, currently housing approximately 5000 residents. Articulated as layers of brises-soleils, Copan's principal western facade undulates along the curve of a small side street (Unai) that defines an inner edge of the lot. This curve wraps around its main entrance on Ipiranga (Fig. 18) and flows away along the other side street (Araujo, Fig. 19). At this hub, the curve draws the sidewalks of these streets and their pedestrian crowds into the building (Figs. 20 and 21), to walk along open-air double-height passageways that are lined with 72 shops, restaurants, and offices, 20 elevators to the upper floors, and one cinema (today an Evangelical church).

Copan supports the dense streetscapes of downtown in three fundamental ways. It does so, moreover, not on staged occasions but in the time of everyday urban life. First, as Fig. 20 depicts, it receives the pedestrian traffic of neighborhood streets into its commercial space directly from the sidewalks along their entire length. As people walk, they can enter the building at almost any point along Araujo, Ipiranga, and Unai. Being porous to these sidewalks along its ground floor, it thus maintains and extends the street-system of public space, offering pedestrians both continuation and destination. In doing so, it articulates in its own body the principal "functions" of city living - work, residence, shopping, entertainment, and traffic - by means of the public spaces of streets and sidewalks.

Second, although open to the sidewalks, the building maintains the edges of the streets that border it. The body of the building is not set back. Rather, it is built out to the lot lines at the sidewalks. Moreover, the façade in elevation does not step away from these sidewalk lines but follows them on both sides (Fig. 22). Although the curving side street Unai pulls the building away from Ipiranga, it becomes parallel to the main street after the curve. Thus Copan's great vertical face follows the line of Ipiranga along this street. As it slips behind the considerably lower tower of its neighbor, its massive elevation therefore reinforces Ipiranga, forming part of its container wall and maintaining its quality as a figural space.

Finally, the street level of Copan is a place of intense sociality (Figs. 23-26). Every time I have been there - now many times over several decades - the open commercial area has always been full of people. Not only do people use the stores and offices, but they also have conversations in small clusters in the open but still protective spaces of the passageways that flow off the street. They meet in front of a coffee bar, have an espresso, chat at one spot or another in meetings of two's and three's, perhaps impromptu or perhaps arranged, but obviously with a sense that they can be both public and private at the same time. Thus, it is not only or even mostly the instrumentality of shopping that

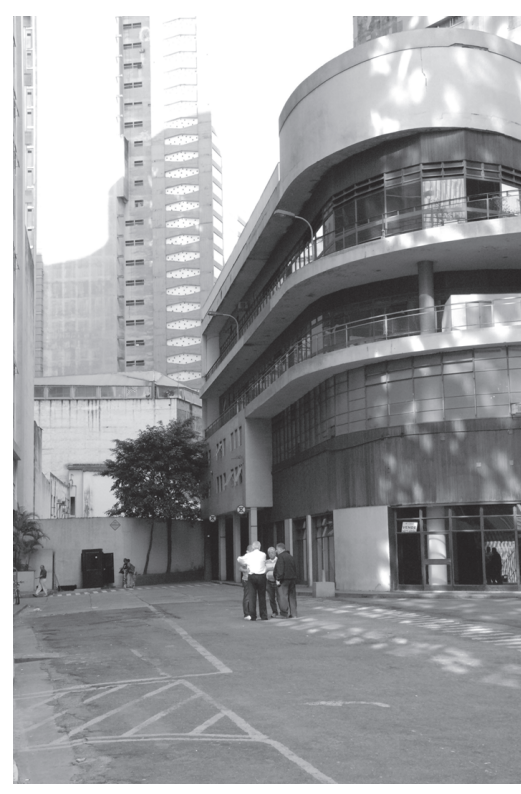

26. Copan, "civic square," 2009. 


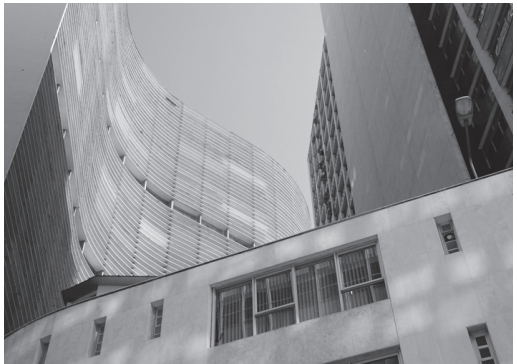

27. Copan, play of solids and voids seen from side "civic square," 2009.

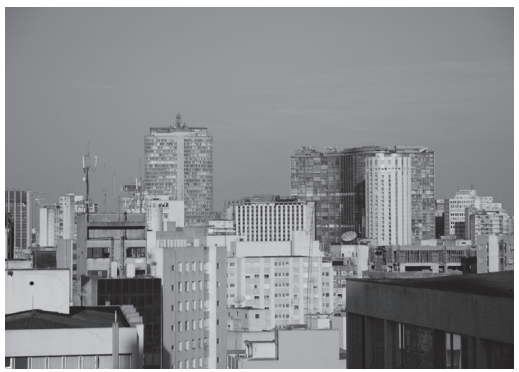

28. View of Copan and neighboring buildings seen from across the city, 2009.

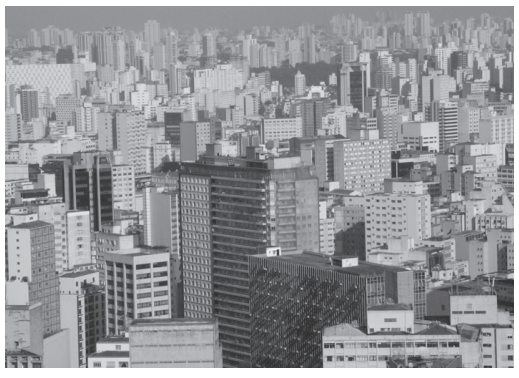

29. View of central São Paulo from the Edifício Italia, 2009. brings these people into conversation. People meet there because the architected spaces foster a public and in that sense civic sensibility about urban conversation. These are reliably good spaces for an quick informal talk.

Especially compelling is the way this urban architecture creates these civic spaces. They are not produced by Copan alone. They result from the density of many streets and buildings, a co-production. Thus even the exterior space at the side of Copan between it and its neighborhood - in fact an intersection of streets - functions like a small civic square (Figs. 25 and 26). Such a space would no doubt be merely no-man's land if these building had been given typical modernist planning and pulled into their lots away from the streets. Instead, where Unai intersects with another small side street (a dead end one called Vila Normanda in Fig. 20 but today renamed), the buildings in proximity create a small, relatively intimate and quite outdoor room. It is supported by a café with chairs on the sidewalk on one side that was not originally planned - an "after thought" frequented by pedestrians but rarely a car - and populated by clusters of people in conversation (Fig. 25).

What creates this outdoor public room, this figural void, is the dense layering of modernist buildings that engage each other in their own conversations. They are able to do so precisely because they remain on and open to the streets, rather than follow the typical modernist site planning of being detached from them. The street logic of this site planning ensures a density of construction sufficient to generate an urban montage in which solids and voids discourse with each other as figures and ground (Fig. 26). To create this dialogue, the buildings do not have to be contiguous, as in the older urbanism. In central São Paulo, in fact, they are mostly freestanding. However, they are proximate enough to ensure that the spaces between them become figural voids in the dynamic tension generated between their surfaces, as seen by pedestrians from different perspectives.

Furthermore, as Figs. 22, 27, and 28 demonstrate, this density generates a play between figural solids and figural voids, as figure and ground shift back and forth between building and space. For the pedestrian, this perceptual play is full of surprises. Standing in the "civic square" at the side of Copan, I look up to see intriguing shapes and volumes, reversible figures and ground (Fig. 27). Walking up a neighborhood street or looking across the city (Fig. 28), I perceive Copan sometimes as ground revealing other shapes - the round tower of the old Hilton Hotel, for example - and sometimes as undulating figure. This perceptual play produces an interesting and engaging cityscape for people, especially pedestrians.

Central São Paulo is a chaos of tall buildings, a city "standing up" (Fig. 29). There is no aesthetic coordination of this extraordinary density, other than the distribution of buildings along the street system of traffic (itself intense and chaotic). Rather, the eye perceives in any 
direction a montage of superimpositions, clashing juxtapositions, collages of contradictory materials and styles. Many of the individual elements in this montage could justifiably be described as aesthetically impoverished, if not "ugly." Yet these judgments are simply irrelevant to the excitement of the city's dense layering: One happenstance view along the sidewalk (Fig. 30) reveals four modern styles of building clashing against each other, a juxtaposition that makes one think (even without especially wanting to, even if half unconsciously) about the nature of architecture, about what it means to construct and inhabit a city.

In the montage of São Paulo's cityscape, Copan is one piece, a remarkable one to be sure, but one piece of an ensemble in which the ordinary and the ugly also become interesting for their participation. Such transformation exemplifies the creativity and exhilaration of modern urbanism. However, it is a modernism very different from that of Brasília and the Memorial. Its copies and transplants comprise hundreds of buildings with similar fenestration and massing, specific tokens derived from general types - like Copan itself in relation to Le Corbusier's Unité d'Habitation. They belong to a street-based and multi-layered cityscape that creates a participatory public of people and buildings engaging each other. By their collective effort, the sum becomes great urban architecture.

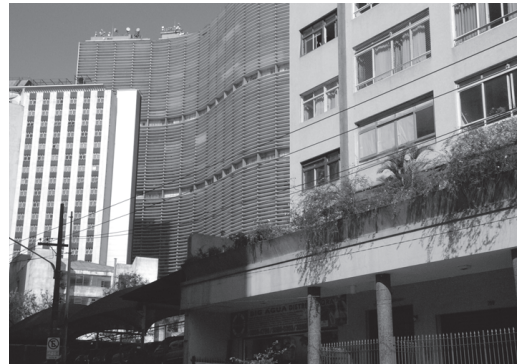

30. View of Copan and neighboring buildings seen from a nearby street, 2009.

All photographs by the author, unless otherwise noted.

\footnotetext{
$1 \rightarrow$ Earlier versions of this essay were delivered at two conferences: one sponsored by the Aga Khan University and Award for Architecture, in Vancouver, Canada (February 2009), on "Homogenization of Representations"; and the other by the University of Coimbra in Coimbra, Portugal (November 2009), on "Crisscrossing Anthropology and Architecture." I am grateful to the organizers of these conferences for their encouragements in discussion and hospitalities in travel. $2 \rightarrow$ There are many historically-oriented studies of modernist architecture in Brazil. They may be grouped in terms of the final period of architectural production they consider: Goodwin (1943) up to the early 1940s, Mindlin (1956) the mid 1950s (before Brasília), Bruand (1981), Ficher and Acayaba (1982), and Lemos (1979) the 1970s, and Arantes et al. (2004) and Cavalcanti and Corrêa do Lago (2005) the mid 2000s. On Brazilian modernism in other fields, see Martins 1969. Specifically on Brasília, see Holston 1989 and 2001; Belo Horizonte, Lara 2008; and Rio de Janeiro, Czajkowski 2000. Interestingly, I could find no book solely on modern architecture in São Paulo. Furthermore, there is very little, if any discussion in the general architectural studies I cite above on the density of modern residential and commercial construction in downtown São Paulo that I consider in this essay. Perhaps that is because the design of most of this construction is not considered "star quality" but only "ordinary modern," and architecture books tend to focus on stars. Thus there are books on São Paulo's individual star architects and, in the general studies, some treatment of their (star) buildings in the city. However, these are overwhelmingly single structures (often houses) presented without discussion or illustration of their urban context. Even the well-known Copan receives scant attention and, when it does, it is only as a single structure decontextualized. Is the obsession in architectural criticism and education with "stardom" (with individual star architects and buildings) the best approach to an architecture for and of cities, most of which will inevitably be "ordinary modern"?
} 
$3 \rightarrow$ It is widely heard in Brazil that Niemeyer's architecture has a baroque

aspect. Such comments point to the curving and "lyrical" lines of his massing and

to the iconic quality of some of his forms. The Cathedral in Brasilia is a good

example of the latter, readily recognizable as a "crown of thorns" or "two hands

in prayer," as many people describe it. I argue in the main text that follows

that modernist urban planning is antithetical to baroque planning in theory and

eliminates it in practice. I also show that it produces buildings that are always

figural and that the dynamism of baroque cities depends on rhetorical principles

other than iconicity. That some of Niemeyer's are especially iconic says more

about their ability to communicate quickly and effectively as "one-liners" - and

their limitations as such - than about any deeper baroque sensibility.

$4 \rightarrow$ For a study of the politics and aesthetics of autoconstruction, see Holston

1991.

$5 \rightarrow$ See Fig. 2 which shows all of Brasilia's main zones in one view and shows

that they are all treated with the same representational and spatial logic.

$6 \rightarrow$ Le Corbusier proclaimed the death of the street in an article first published

in the French syndicalist newspaper L'Intransigeant in 1929. An expanded version

was republished in the syndicalist review Plans 5 (May 1931). This version is

reprinted in Le Corbusier's Radiant City (1933).

Referências bibliográficas

Arantes, Pedro Fiori, Roberto Conduro, João Masao Kamita, Luiz Recamán, and Guilherme Wisnek. 2004. Arquitetura Moderna Brasileira. London: Phaidon Press.

Bruand, Yves. 1981. Arquitetura Contemporânea no Brasil. São Paulo: Editora Perspectiva.

Cavalcanti, Lauro, and André Corrêa do Logo. 2005. Ainda Moderna? Arquitetura Brasileira Contemporânea. Rio de Janeiro: Editora Nova Fronteira.

Ficher, Sylvia, and Marlene Milan Acayaba. 1982. Arquitetura Moderna Brasileira. São Paulo: Projecto Editores.

Goodwin, Philip. 1943. Brazil Builds: Architecture New and Old, 1652-1942. New York: The Museum of Modern Art.
Holston, James. 1989. The Modernist City: An Anthropological Critique of Brasília. Chicago: University of Chicago Press.

1991. Autoconstruction in working-class Brazil. Cultural Anthropology 6(4): 447-465.

2001. The spirit of Brasilia: modernity as experiment and risk. In Brazil Body \& Soul, 540-557. Edited by Edward J. Sullivan. New York: The Solomon R. Guggenheim Museum.

Lara, Fernando Luiz. 2008. The Rise of Popular Modernist Architecture in Brazil. Gainesville: University Press of Florida.

-

Le Corbusier (Charles Edouard Jeanneret). 1967. The Radiant City: Elements of a Doctrine of Urbanism to Be Used as the Basis of Our Machine-Age Civilization. New York: Orion Press. Original edition, 1933.
Lemos, Carlos. 1979. Arquitetura Brasileira. São Paulo: Editora Melhoramentos.

-

Mindlin, Henrique. 1956. Modern Architecture in Brazil. São Paulo: Editora Colibris.

-

Martins, Wilson. 1969. O Modernismo, 1916-1945. São Paulo: Editora Cultrix.

Schwarz, Roberto. 1977. As idéias fora do lugar. In Ao Vencedor as Batatas: Forma Literária e Processo Social nos Inícios do Romance Brasileiro. São Paulo: Livraria Duas Cidades. 